Saudi Journal of Biomedical Research

Abbreviated Key Title: Saudi J Biomed Res ISSN 2518-3214 (Print) |ISSN 2518-3222 (Online)

\title{
Studies on Acute Phase Inflamatory Proteins of Type 2 Diabetics in Owerri
}

\author{
Edward Ukamaka C*, Nwanjo Harrison U, Nwosu Dennis C \\ Department of Medical Laboratory Science, Imo State University, Owerri, Nigeria
}

\author{
\begin{tabular}{ll}
\hline DOI: $10.36348 /$ SJBR.2019.v04i10.002 & | Received: 02.10.2019| Accepted: 09.10.2019|Published: 11.10.2019
\end{tabular} \\ *Corresponding author: Edward Ukamaka C \\ Abstract
}

Type 2 diabetes mellitus is a chronic metabolic disorder which has emerged as a health challenge globally due to its insidious on set, late recognition and complications. The present study was aimed at evaluation of acute phase inflammatory proteins in Owerri. Cross Sectional Studies was conducted at Federal Medical Center and Imo State specialist Hospital, Owerri. A total of three hundred subjects which include each one hundred and fifty type 2 diabetics and apparently control subjects between the ages forty and sixty nine years were recruited. Ten millimeters of venous blood was aseptically collected from the subjects. Spectrophotometric, nephlometric, enzyme immunoassay were used for determination of these parameters. The data was analyzed using statistical package for social science 20.0. Test with a probability value of $\mathrm{P}<0.05$ was considered statistically significant. Result from acute phase inflammatory proteins showed that the mean value of c-reactive protein alpha 1-acid glycoprotein, alpha1- antitrypsin, haptoglobin and ceruloplasmin in type 2 diabetics $(5.21 \pm 0.91 \mathrm{mg} / \mathrm{l}, 99.34 \pm 17.84 \mathrm{mg} / \mathrm{dl}, 152.32 \pm 26.69,154.03 \pm 7.75 \mathrm{mg} / \mathrm{dl}, 47.83 \pm$ $6.20 \mathrm{mg} / \mathrm{dl})$ were higher which was statistically significant $(\mathrm{P}=0.001)$ when compared with the control subjects $(3.14 \pm$ $0.80 \mathrm{mg} / \mathrm{l}, 76.86 \pm 12.41 \mathrm{mg} / \mathrm{dl}, \quad 114.94 \pm 16.11 \mathrm{mg} / \mathrm{dl}, \quad 132.80 \pm 79 \mathrm{mg} / \mathrm{dl}, 34.47 \pm 3.75 \mathrm{mg} / \mathrm{dl})$. There was statistically significant progressive decrease $(\mathrm{P}=0.04)$ in $\mathrm{c}$ - reactive protein $(5.50 \pm 0.98,5.08 \pm 0.84,5.04 \pm 0.83 \mathrm{mg} / \mathrm{l})$;significant increase $(\mathrm{P}=0.001)$ in haptoglobin $(149.40 \pm 7.78,155.96 \pm 7.93,157.84 \pm 6.12 \mathrm{mg} / \mathrm{dl})$ and ceruloplasmin $(45.54 \pm 6.84$, $46.92 \pm 5.79,51.44 \pm 6.12 \mathrm{mg} / \mathrm{dl})$.The mean value alpha1-acid glycoprotein in female type 2 diabetics was statistically significantly higher $(\mathrm{P}=0.001)$ when compared to male $(10.912 \pm 17.29 \mathrm{v} 89.55 \pm 0.19 \mathrm{mg} / \mathrm{dl})$.

Keywords: Acute Phase Inflamatory Proteins, Type 2 Diabetics, Spectrophotometric, chronic metabolic disorder, nephlometric.

Copyright @ 2019: This is an open-access article distributed under the terms of the Creative Commons Attribution license which permits unrestricted use, distribution, and reproduction in any medium for non-commercial use (NonCommercial, or CC-BY-NC) provided the original author and source are credited.

\section{INTRODUCTION}

Diabetes Mellitus is a chronic metabolic disease which is associated with a high incidence rate of morbidity and mortality globally. Type 2 diabetes mellitus is the most prevalent one and makes up $90 \%$ of cases of diagnosed diabetes [1]. Type 2 diabetes mellitus formerly known as non-insulin dependent diabetes mellitus or adult-onset diabetes is a metabolic disorder that is characterized by hyperglycaemia due to insulin resistance and relative reduced insulin secretion by beta pancreatic cells [2]. This disease is relentlessly affecting on economically affluent nations and afflicting developing country such as Nigeria .The regional prevalence of type 2 diabetes mellitus in Nigeria has been reportedly variable across different parts of the country which could be a reflection of genetic, cultural, tribal, diet and life style [3]. International Diabetic Federation [4] reported that 425 million $(8.8 \%)$ adults between the ages of twenty to seventy - nine years had diabetes and predicted to rise up to $625(9.9 \%)$ by the year 2045. According to Adeloye et al., [5], the pooled prevalence of type 2 diabetes in Nigeria in 2017 was $5.7 \%$. In Imo State, the prevalence of type 2 diabetes was $8.7 \%$ was which reported among geriatric individuals [6].

Active innate Immune cells in response to inflammation are a part of host defense and if uncontrolled, the inflammatory response induces persistent hyper expression of pro-inflammatory mediators and tissue damage. Complex interaction in fat tissues draws immune system to the area and trigger low - level chronic inflammation and type 2 diabetes mellitus [7]

The positive acute phase proteins inclusde Creactive protein, alpha 1- antitrypsin, alpha 1- acid glycoprotein, haptoglobulin, ceruloplasmin while the negative acute phase proteins include albumin, transferrin transthyretin and others [8]. 
C- reactive protein is an inflammatory marker originally found in sera of those that reacted with c polysaccharide within cellular wall of Streptococcus pnuemonia produced and released by the liver under the stimulation of pro inflammatory cytokines such as interleukin 1 and 6, tumor necrosis factor $\alpha[9,10]$. Alpha 1 - antitrypsin is a protease inhibitor which protects tissue from enzyme inflammatory cells especially neutrophil elastase, but the concentration rises many fold upon acute inflammation, pregnancy, oral contraceptive [11]. Alpha 1-acid glycoprotein also known as orosmucoid is a protein that binds lipophilic substances and its plasma concentration is increased in several fold in acute phase response especially gastrointestinal inflammatory disease and malignant neoplasms [11]. Haptoglobin is an alpha 2 glycoprotein synthesized primarily by hepatocytes [12]. It has polymorphism namely $\mathrm{Hp} 1-1, \mathrm{Hp} 2-1, \mathrm{Hp} 2-2$ which binds free haemoglobin to form haemoglobin haptoglobulin complex which prevents loss or damage in oxidative damage and associate in clinical evolution of several inflammatory disease [13]. Ceruloplasmin is an alpha 2 - glycoprotein which is synthesized in the liver and carries $90 \%$ of total copper in healthy and is involve on redox reaction; oxidation of ferrous iron to ferric iron, assisting transferrin and the increase can be used to measure degree of inflammation [14].

The study was done to evaluate the levels of acute phase inflammatory proteins in Type 2 Diabetics in Owerri.

\section{MATERIALS AND METHODS Study Area}

The cross sectional study was conducted at Federal Medical Centre, Owerri and Imo State Specialist Hospital, Owerri.

\section{Study Population}

The sample size for the study was calculated using the formula below, according to Aronye [15]. The prevalence rate of type 2 diabetes mellitus in Imo State is $8.7 \%$ [6]

$$
\mathrm{n}=\mathrm{z}^{2} \mathrm{p}(\mathrm{q}) / \mathrm{d}^{2}
$$

Where

$$
\begin{aligned}
& \mathrm{q}=1-\mathrm{P} \\
& \mathrm{n}=\text { Sample size } \\
& \mathrm{p}=\text { prevalence of type } 2 \text { of diabetes mellitus in } \\
& \text { Imo State- } 8.7 \% \\
& \mathrm{z}=\text { confidence interval } 95 \%-1.96 \\
& \mathrm{~d}=\text { Degree of accuracy- } 0.05 \\
& \mathrm{n}=1.96^{2} \times 0.087(1-0.087) / 0.05^{2}=3.8416 \mathrm{x} \\
& 0.07943 / 0.0025 \\
& =122.057=122 \\
& \text { Therefore, the minimum sample size will be } \\
& 122 .
\end{aligned}
$$

\section{Subjects}

Three hundred subjects of both sex between the ages of fifty to sixty-nine years were recruited for the study. One hundred and fifty type 2 diabetics attending clinic of Federal Medical Centre, Owerri and Imo State Specialist Hospital, Owerri for at least six months were eligible for the study. Also, one hundred and fifty apparently healthy individuals were recruited who came for check up for medical fitness and served as the control subjects.

They were further grouped according to their ages 40-49, 50-59 and 60-69 years, and also according to sex; male $(n=75)$ and female $(n=75)$

\section{Parameters Studied}

The parameters evaluated in this study include c-reactive protein, alpha 1- acid glycoprotein, alpha 1antitrypsin, haptoglobin, ceruloplasmin.

\section{Study Design}

This is a cross-sectional study that involved type 2 diabetics and control subjects.

This was divided into four phases.

- Phase I: The glucose level of study subjects were confirmed using a standard technique

- $\quad$ Phase II: Acute phase inflammatory proteins; C- reactive, protein, alpha 1-acid glycoprotein, alpha 1- antitrypsin, haptoglobin and ceruloplasmin were determined using a standard technique

\section{Site of the Study}

The analysis was carried out at the chemical pathology laboratory of the Department of Medical laboratory Science of Imo State University, Owerri and Federal Medical Center, Owerri through a letter obtained from the Head of Department through my Supervisor.

\section{Laboratory Procedure}

All reagents were commercially purchased and the manufacturer's standard operating procedures were strictly adhered to.

\section{A Determination of Glucose}

This was carried out by enzymatic oxidase peroxidase method according to Tietz et al., 2006 as modified by Randox Laboratories, United Kingdom. Catalog number; GL 1021, GL 304, GL366.

\section{Procedure}

Three dry cleaned plain test tubes were setup in a jack, labeled test, standard and blank. Then, $20 \mu 1$ of sample and standard wore pipetted into the tubes labeled these and standard respectively. In all the tubes, $2000 \mu \mathrm{l}$ of reagents I was added. The tubes were gently mixed, incubated at $37^{\circ} \mathrm{C}$ for 10 minutes. The 
absorbance of sample and standard were read spectrophotometrically at $500 \mathrm{~nm}$.

\section{Determination of C - reactive Protein}

The test was carried out by immunotubidimetric assay, according to Zeigenhagen et al., [17] as modified by Agappe Diagnostic, Switzerland.Catalog number: 51808001, 51808802.

\section{Procedure}

The test was performed using MISPA - L2 auto analyzer which had a slot for smart card. A smart card was used which contained the test procedure steps and the calibration data. The smart card was inserted into the card reader slot and there was a display which prompted to add Reagent I and the sample. The sample curvette was placed into the curvette holder, $150 \mu \mathrm{L}$ of glycine buffer and $5 \mu \mathrm{L}$ of the sample were added. It was automatically incubated for a few seconds. After incubation, another display was shown on the screen which prompted to add reagent 2. Using an attached sensor pipette, $150 \mu \mathrm{L}$ of latex suspension coated with anti-CRP antibodies was pipette into the curvette. The result was displayed on the screen and was recorded.

\section{Determination of Alpha 1 - Antitrypsin}

The test was carried out by nephrometric immunoassay according to Bergstrom et al., [18] as modified by Agappe Diagnostic,

Switzerland. Catalog Number: 52009013, 52009037

\section{Procedure}

The test was performed using MISPA - L2 auto analyzer which have a slot for smart card. The smart card contained the test procedure steps and the calibration data.The smart card was inserted into the card reader slot and there was a display that prompted to add reagent I and the sample. The sample curvette was placed into the holder, $120 \mu 1$ of glycerin buffer and $10 \mu \mathrm{l}$ with normal saline was pipette into itaccordingly. It was automatically incubated for few seconds.After incubation, there was another display which, prompted to add reagent 2, using attached sensor pipette into it. The result was displayed on the screen and was recorded.

\section{Determination of Alpha 1 - Acid Glycoprotein \\ This was carried out by nephelometric immunoassay method according to chmidt [19] as modified by Agappe Diagnostics, Switzerland .Catalog number: 52009011, 5200928}

\section{Procedure}

The test was performed using MISPA - L2 auto analyzer which had a slot for smart card. The smart card contained the test procedure steps and the calibration data. The smart card was inserted into the slot card reader and there was a display that promoted to add reagent I and the sample. The sample curvette was placed into the holder $150 \mu \mathrm{l}$ of poly ethylene glycol and $7 \mu \mathrm{l}$ of sample was pipette into it. It was automatically incubated for few seconds. After incubation, there was another display which prompted to add reagent 2 . Then, $150 \mu 1$ of polyclonal goal anti human alpha 1 - acid glycoprotein antibodies was pipetted into the curvette using attached sensor pipette. The result was displayed on the screen and was recorded.

\section{Determination of Haptoglobin}

This was carried out by nephelometric immunoassay according to Jacobs et al. (1984) as modified by Agappe Diagnostic Switzerland. Catalogue number 52009024, 5200943.

\section{Procedure}

The test was performed using MISPA- $\mathrm{L}_{2}$ auto analysis which had a slot for smart card. The smart card contained the test procedure steps and the calibration data. The smart card was inserted into the slot card reader and there was a display that prompted to add reagent and the sample. The sample curvette was placed into the holder $100 \mu \mathrm{l}$ of $\mathrm{R}_{1}$ (tribuster arPh 7.4) was pipette into it. Then, $S \mu l$ of serum diluted with $1 / 2$ of $R_{3}$ normal saline) was added. It was automatically incubated in a few seconds. There was another display which prompted to add reagent 2 and $200 \mu \mathrm{l}$ of $\mathrm{R}_{2}$ (polyclonal anti human haptiglobin antibodies) was added using attached sensor pipettor. These result was displayed on the screen and was revealed

\section{Determination of Ceruloplasmin}

The test was carried out by nephelometric immunoassay according to Jacobs et al., [20] as modified by Agappe Diagnostic, Switzerlan d. Catalogue number: 52009019, S2009042.

\section{Procedure}

The test was performed using MISPA- $\mathrm{L}_{2}$ autoanalyzed which had a slot in the smart card. The smart card contained the test procedure steps and the calibration data. The smart card was inserted into the slot card reader and there was a display that prompted to add reagent 1 and the sample. The sample curvette was inserted into the holder, $100 \mu 1$ of R1 (Phisphate buffered saline) was pipette into it $5 \mu \mathrm{l}$ of serum was added. It was automatically incubated for a few seconds, there was another display which prompted to add reagent 2 and $150 \mu 1$ of R2 (polyclonal anti human ceruloplasmin antibodies was added into the curvette. The result was displayed on the screen and was recorded. 


\section{RESULTS}

Table-1: Comparison of the Mean Values of Acute Phase Inflammatory Proteins In Type 2 Diabetes Mellitus and Control Subjects in the Study Population.

\begin{tabular}{|l|l|l|l|l|}
\hline Parameters & $\begin{array}{l}\text { Type 2 diabetes } \\
\text { Mellitus subjects } \\
(\mathbf{n = 1 5 0 )} \\
\text { mean } \pm \text { SD }\end{array}$ & $\begin{array}{l}\text { Control subjects } \\
(\mathbf{n = 1 5 0 )} \\
\text { mean } \pm \text { SD }\end{array}$ & T-test & P-Value \\
\hline C -reactive protein (mg/L) & $5.21 \pm 0.91^{*}$ & $3.41 \pm 0.80$ & 8.888 & 0.0001 \\
\hline Alpha 1- glycoprotein (mg/dL) & $99.34 \pm 17.84^{*}$ & $76.86 \pm 12.41$ & 12.667 & 0.0001 \\
\hline Alpha 1- antitrypsin (mg/dL) & $152.32 \pm 26.69^{*}$ & $114.94 \pm 16.11$ & 14.682 & 0.0001 \\
\hline Haptoglobin (mg/dL) & $154.03 \pm 7.75^{*}$ & $132.80 \pm 7.69$ & 23.814 & 0.0001 \\
\hline Ceruloplasmin (mg/dL) & $47.83 \pm 6.20^{*}$ & $34.47 \pm 3.75$ & 22.589 & 0.0001 \\
\hline
\end{tabular}

\section{KEY}

\author{
$\mathbf{n}$ : Number of subjects in each group \\ *: statistically significant when compared with \\ type 2 diabetic group $(\mathrm{P}<0.05)$.
}

Table-1 shows the mean values of some acute phase inflammatory proteins; creactive protein, alpha1acid glycoprotein and alpha1-antitrypsin, haptoglobin and ceruloplasmin in type 2 diabetics and control subjects.

Result obtained from this study showed that the mean value of c-reactive protein $(5.21 \pm 0.91)$ was higher in type 2 diabetics which statistically significant $(\mathrm{p}=0.001)$ when compared with mean value $(3.41 \pm$ $0.80)$ of the control subjects.

The mean value of alpha 1 - acid glycoprotein $(99.34 \pm 17.84)$ was higher in type 2 diabetics which was statistically significant $(\mathrm{p}=0.0001)$ when compared with the mean value $(76.86 \pm 12.4)$ of the control subjects.

The mean value of alpha 1 - antitypsin (152.32 \pm 26.69) was higher in type 2 diabetics which was statistically significant $(\mathrm{p}=0.0001)$ when compared with the mean value $(114.94 \pm 16.11)$ of the control subjects.

Result from this study showed that the mean value of haptoglobin $(154.03 \pm 7.75)$ was higher in type 2 diabetes which was statiscally significant $(\mathrm{p}=0.0001)$ when compared with the mean value $(132.80 \pm 7.69)$ of the control subjects.

The mean value of ceruloplasmin $(47.83 \pm 6.20)$ was higher in type 2 diabetes which was statistically significant $(\mathrm{P}=0.0001)$ when compared with the mean value $(34.47 \pm 3.75)$ of the control subjects.

Table-2: The Mean Values of Measured Parameters of Acute Phase Inflammatory Proteins Parameters in Type 2 Diabetes Mellitus Subjects in Relation to Age of the Study Population.

\begin{tabular}{|l|c|l|l|l|l|l|l|}
\hline Parameters & $\begin{array}{l}\mathbf{4 0 - 4 9} \text { Years } \\
(\mathbf{n = 5 0}) \\
\text { mean } \pm \text { SD }\end{array}$ & $\begin{array}{l}\text { 50-59 Years }(\mathbf{n = 5 0}) \\
\text { Mean } \pm \text { SD }\end{array}$ & $\begin{array}{l}\mathbf{6 0 - 6 9} \\
(\mathbf{n}=\mathbf{5 0}) \\
\text { mean } \pm \text { SD }\end{array}$ & F-value & P-value & $\begin{array}{l}\text { P-value } \\
\text { a vs b }\end{array}$ & $\begin{array}{l}\text { P-value } \\
\text { b vs c }\end{array}$ \\
\hline C -reactive protein (mg/L) & $5.50 \pm 0.98$ & $5.08 \pm 0.84^{*}$ & $5.04 \pm 0.83$ & 4.183 & 0.017 & 0.048 & 0.972 \\
\hline Alpha 1- glycoprotein (mg/dL) & $105.58 \pm 23.7$ & $95.18 \pm 14.9^{*}$ & $97.24 \pm 11.0$ & 5.021 & 0.008 & 0.009 & 0.824 \\
\hline $\begin{array}{l}\text { Haptoglobin (mg/dL) } \\
\text { Ceruloplasmin (mg/dL) }\end{array}$ & $149.40 \pm 7.78$ & $155.96 \pm 7.73^{*}$ & $157.84 \pm 7.69$ & 8.207 & 0.001 & 0.010 & 0.667 \\
\hline Alpha 1- antitrypsin (mg/dL) & $45.84 \pm 6.84$ & $46.92 \pm 5.79$ & $51.44 \pm 6.12^{* *}$ & 5.627 & 0.005 & 0.815 & 0.034 \\
\hline Malondialdehyde(nmol/L) & $169.83 \pm 26.4$ & $143.64 \pm 22.7^{*}$ & $143.48 \pm 21.9$ & 20.332 & 0.0001 & 0.0001 & 0.999 \\
\hline
\end{tabular}

KEY

n: Number of subjects in each group

p - value: $P$ - value across all type 2 diabetics age groups

p valuea vs b: P-value of comparison between the age group of $40-49$ and 50-59 years in type 2 diabetics

$P$ valueb vs c: $\mathrm{P}$-value of comparison between the age group of 50-59 and 60-69 years

*: statistically significant when compared between the ages of 40-49 years $(\mathrm{P}<0.05)$.

**: statistically significant when compared between the ages of 50-59 years $(\mathrm{P}<0.05)$.
Table- 2 shows the mean values of $\mathrm{C}$-reactive protein, alpha 1-acid glycoprotein, alpha1- antitypsin in type 2 diabetics in relation to age.

Result from this study showed that there was progressive decrease in the mean value of $\mathrm{C}$ - reactive protein across all the age groups $((5.50 \pm 0.98 ; 5.08 \pm$ $0.84 ; 5.04 \pm 0.83$ ) which was statistically significant (p $=0.017)$. The mean value was increased between the ages of 50-60 years (5.08 \pm 0.84) which was statistically significant $(\mathrm{P}=0.048)$ when compared with the ages between $40-49$ years $(5.50 \pm 0.98)$. While the mean value between the ages of 60 - 69 years $(5.04 \pm$ 0.83 ) decreased, which was statistically not significant 
$(\mathrm{P}=0.972)$ when compared with the mean value $(5.08 \pm$ 0.84 ) between the ages of 50-59 years.

There was non-progressive decrease in the mean value of alpha 1- acid glycoprotein between all the age groups $(105.58 \pm 23.7 ; 95.18 \pm 14.9 ; 97.24 \pm$ $11.0)$ which was statistically significant $(\mathrm{p}=0.008)$. The mean value between the ages of 50-59 years $(95.18 \pm$ 14.9) was decreased which was statistically significant $(\mathrm{P}=0.009)$ when compared with value between the ages of 40 - 49 years $(105.58 \pm 23.7)$ while between the ages of 60 - 69 years $(97.24 \pm 11.0)$, there was an increase which was not statistically significant $(P=0.824)$ when compared with the value between the ages of 50-59 years $(95.18 \pm 14.9)$.

The mean value of the alpha 1 - antitrypsin across all age groups $(169.53 \pm 26.4 ; 143.64 \pm 22.7$; $143.48 \pm 21.9$ ) was non progressively decreased which was statistically significant $(\mathrm{p}=0.0001)$. The mean value between the ages of 50-59 years (143.64 \pm 22.7) drastically decreased which was statistically significant $(\mathrm{P}=0.010)$ when compared with the ages between 40-49 years $(169.53 \pm 26.4)$. There was no significant difference $(\mathrm{p}=0.999)$ in the mean value of alpha 1antitrypsin between the ages of 50-59 years (143.64 \pm $22.7)$ and 60-69 years (143.48 \pm 21.9$)$.

Result showed that there was progressive increase in the mean value of haptoglobin across the age groups $(149.40 \pm 7.78 ; 155.96 \pm 7.73 ; 149.40 \pm$ 7.78) which was statistically significant $(\mathrm{P}=$ $0.001)$. The mean value between the ages of $50-59$ years $(155.96 \pm 7.73)$ was increased which was stastically significant $(\mathrm{p}=0.01)$ when compared with the ages between 40 - 50 years $(149.40 \pm 7.78)$. There was increase in the mean value in ages between $60-69$ years $(157.84 \pm 7.69)$ which was not statistically significant when compared with the ages between 50 59 years.

The mean value of ceruloplasmin across the age groups $(5.8 \pm 6.84 ; 46.42 \pm 5.79 ; 51.44 \pm 6.12)$ progressively increased but was statistically not significant $(\mathrm{p}=0.005)$. There was increase, in the mean value between thr ages of 50-59 years $(46.42 \pm 50.79)$ which was not statistically significant $(\mathrm{p}=0.815)$ when compared with the mean value of ages between 40-49 years $(45.8 \pm 6.84)$. The mean value between the ages of 60-69 years $(51.44 \pm 6.12)$ increased which was statistically significant when compared with result in ages between 50-59 years (46.42 \pm 5.79$)$.

\section{DISCUSSION}

In this present study, higher level of Creactive protein was observed in type 2 diabetes when compared with the control subjects. $\mathrm{C}$ reactive - protein is an acute phase protein, a physiological biomarker of subclinical inflammation which is synthesized by hepatocytes, produced by proinflmmatory cytokines mainly interleukins IL-1, IL-6, tissue necrosis factor alpha in 1000 folds to stimulate the classical pathway in response to inflammation associated with hyperglycaemia, insulin resistance and type 2 diabetes. Also, C reactive protein is a strong predictor of increased cardiovascular risk in type 2 diabetes mellitus due to increase inflammatory activity in arterial walls which result in endothelial dysfunction by stimulation of endothelial cells expression of intracellular cell adhesion molecules (I CAM -1) and vascular cell adhesion molecules -1 (VCAM-1) this result in formation of atherosclerosis formation of thrombosis which may lead to cardiovascular risks such myocardial infarction ,coronary artery disease, hypertension accompanied in type 2 diabetes. The present study is consistent with previous studies that found a positive association between $\mathrm{C}$ - reactive protein and type 2 diabetes. Tabassum et al., [21] reported significant higher level of $\mathrm{C}$ - reactive protein and fasting blood glucose in diabetes which indicated possible role in diabetic pathogenesis. Similarly, in a recent study, Cheng et al., [22], observed that long term inflammation mediated by inflammatory markers such as $\mathrm{C}$-reactive protein was due to increase in body mass, waist circumference that plays a role in development of type 2 diabetes. Mohiedelin et al., [23] reported significant elevated level of high sensitive $\mathrm{C}$ - reactive (Hs-CRP) due to dysregulation of glucose and lipid metabolism which affect endothelial function that was associated with cardiovascular diseases in type 2 diabetes. Babu and Joshi [24] reported that significant high level of $\mathrm{C}$ - reactive is associated with microvascular complication due to production of pro inflammatory cytokines released by adipose decreases beta cell mass through interleukin $1 \beta$ induced apoptosis. Saltar et al., [25] reported the level of C- reactive protein and interleukin 6 was two - fold higher than control which indicated progression of complications among obsessed type 2 diabetes mellitus. The observed decrease found in age suggested that $\mathrm{C}$ reactive protein decreased in advanced age. This is because higher systemic subinflammation and central obesity is highly associated with body mass index and waist circumference which is found mostly at the age of forty years and concise with the likely age of onset of type 2 diabetes. This study is in agreement with the work of Svensson et al., [26] and Tutuncu et al., [27] that reported higher $\mathrm{C}$ - reactive protein among people at age of onset due to obesity and accumulation of free fatty acids. Also, Cardoso et al., [28] showed higher CRP which was significantly associated with younger age less than eighty years. Kanmani et al., [29] reported that the association between $\mathrm{C}$ - reactive protein and incidence of type 2 diabetes mellitus which is more prominent among subjects from fifty years due to severe inflammation. The current study found gender difference in the level of $\mathrm{C}$ - reactive protein. Female type 2 diabetes showed higher level of $\mathrm{C}$ - reactive proteins when compared with the male. This may be 
due to action of sex hormone, higher body fat mass or visceral adiposity percentage found in female. The findings of this study are in aggrement with other studies. Gambineri and Pelusi [30] reported that inflammation associated with T2D is more prominent in diabetic women due to hyperandrogenism which contributes to abdominal obesity; insulin sensitivity which influences the finding is accordance with Kanmani et al., [29] that reported higher level of CRP in women due to excess adiposity. Also elevated level was reported by Svensson et al., [26] in female type 2 diabetics. The study is consistent with the study conducted by Abraham et al., [31] that observed higher level of CRP in women due to excess body fat, low adipotectin which results in lipid and glucose dysregulation. Contrary to this study, Tabassum et al., [21] reported no significant difference in $\mathrm{C}$ - reactive protein in both male and female type 2 diabetics.

The present study showed that there was higher level of alpha acid glycoprotein among type 2 diabetics. Alpha 1- acid glycoprotein an acute phase protein stimulated by hepatic mediated proinflammatory cytokines which is involved in low grade inflammation, anti-inflammatory and immunodulatory activities in acute reponse as a result of hyperglycaemia mediated inflammation. This study is in agreement with the work of previous studies. Mohiuddin et al., [32] that reported hihger level of alpha 1-acid glycoprotein jn type 2 diabetics who were involved in low grade chronic system inflammation that triggered the development of insulin resistance and $\beta$ cell dysfunction. Abdulawhab et al., [33] reported that enzymatic glycosylation of this protein is involved in future risk of type 2 diabetes. The study is consistent with the report of by Lee et al., [34] that showed elevation level in alpha 1 acid glycoprotein in T2D due to its immunomodulatory in relief of hyperglycaemia, and modulation of immune response to protect adipose tissue from excessive Inflammation and metabolic dysfunction. Also, Eldosky et al., [35] concluded higher significant increase in AAG production and involvement in subclinical atherosclerosis and cardiovascular risk in non obsessed type 2 diabetics. The association seen with diabetes in our study is in contrast with the findings of Muhammad et al., [36]. The findings of this study showed no significant change in all ages which indicated no inflammatory change in type 2 diabetes in respect to age. This study showed higher level of alpha acid glycoprotein in male compared to female. This may be due to other environmental factor such as unheaithy lifestyles such as diet, smoking, physical inactivity which can promote low grade inflammation, this is in accordance with the study of Eldoski et al., [35] that reported high incidence of type 2 diabetes in male as a result of metabolic factors.

The higher level of alpha 1- antitrypsin observed in type 2 diabetes in this study has shown it role as an acute phase inflammatory marker which participate on the pathogenesis of type 2 diabetes characteristic due to hepatic acute response to tissue damage, stimulated by proinflammatory cytokines such as interleukin 6 , tissue necrosis factor $-\alpha$, interleukin -1 activation of transcription 3 and nuclear factor Kappa $\beta$ (NF-KB). Excess adiposity circulating granulocytes mediates proiflmmatory cytokines contributes to release of alpha I antitrypsin following migration to tissue inflammation. Over expression of alpha 1 antitrypsin in type 2 Diabetes triggers anti inflammatory modulating and anti protease activity activity against neutrohilelastase, colleganase, chymotrypism, Kallikrein, Plasmin. Alpha 1 antitrypsin exert an inhibitory effect on tissue necrosis factor alpha stimulated by endothelial cell activation and involvement in preventing vascular injury in inflammation. Alpha 1 antitrypsin has shown to prolong islet aliograt survival to protect beta cells from cytokine medicated cell injury. This study is in accordance with the study conducted by Mohiuddin et al., [32] that observed higher level of alpha 1 anti trypsin in low grade inflammation associated with hyperglycaemia. This is also in agreement with the work of Kalis et al., [37] that demonstrated an association of alpha 1antitrypsin and insulin secretion which protect $\beta$ cell against cytokine induced apoptisis. Fleixo -Lima et al., [38] reported elevated level of alpha 1-antitrypsin in fourfold during acute phase and protect pancreatic islet $\beta$ cell of type 1 diabetes. Also, Kim 2018 reported that increased level of AAT in pancreases $\beta$ cell apoptosis in type 2 diabetes by inhibiting capase 3 proteolysis. McCanthy et al., [39] reported that alpha, antitrypsin as an acute phase protein that is not only significantly elevated but involve glycosylated altercation.

Higher level was observed in the level of haptoglobin in type 2 diabetets when compared with the control subjects. Haptoglobin is acute phase alpha glycoprotein which is synthesized primarily in the liver and the other tissues in responses to excess adiposite pro-inflammatory cytokines hyperglycaemia induced low- grade inflammation. Haptoglobiin possess antioxidant property and anti- inflammatory effect by removing heme compounds which catalyses oxidation of arachidonic acid which results in production of excess reactive species. It binds free circulating haemoglobin forming haptoglobin - haemoglobin complex which is removed from circulation via monocyte macrophage cell surface scavenger receptors, hepatic kupfer cells and prevents loss of iron and iron driven oxidative damage. Free haemoglobin is is a relevant potent prooxidant which media intes several oxidative pathway and resulting in the formation of hydroxyl radicals in diabetes In type 2 diabetes, the ability of haptoglobin to protect against haemoglobin driven oxidative injury is abrogated when haemoglobin becomes glycated which accelerates diabetic condition. Glycohaemoglobin-haptoglobin complex is catalytically redox active which prevent its removal from trigger 
circulation. The haptoglobin genotypes have been proved to oxidised LDL, reduced bioavailability of nitric oxide which is associated with macrovascular and microvascular complications in type 2 diabetes The functional allele polymorphisms in haptogloblin gene determines susceptibility to increase in vascular disorder associated with inflammation and oxidative stress in type 2 diabetes. Haptogloblin 1-1 genotype has been proved efficiently to have superior protection by binding free haemoglobin in circulation while haptogloblin 2-2 genotype has incomplete antioxidant mechanism in removal of free haemoglobin that is involved in endothelial dysfunction which enhances cardiovascular complications associated with type .The present study is in line with previous studies. This study agrees with the work of Adinortey et al., [40]. Hamdy et al., [41] reported that haptoglobin phenotype as a risk factor for coronary artery diseases and cardiovascular diseases in type 2 diabetes. Also, Feng et al., [42] reported that haptoglobin 2-2 phenotype is associated with increase acute kidney injury in patients with diabetes mellitus. This study is in accordance with the work of Olaniyan et al., [43] that reported higher level of haptoglobin in Nigeria type 2 diabetes due there was a high frequency of Hp 2-2 allele gene genotype which led to vascular complications. The decreased level observed in as the ages progress may result in increased cerebrovascular disease, neuropathological process or cognitive function. This is in agreement with the work of Mohieldein et al., [44] that reported that decline in haptoglobin 1-1 2-1 and 2-2 were associated with poor cognition, cerebrovascular disease, greater risk of myocardial infarction and mortality.

Higher level of ceruloplasmin was observed in type 2 diabetics when compared with the control subject. Ceruloplamin is an acute phase inflammatory protein which is released by cell mediated pro inflammatory cytokines in excess adipose tissue which is associated with chronic low grade inflammation accompanied by insulin a copper - carrying metalloenzyme which acts as an antioxidant through its ferroxidase activity where it oxidises ferrous iron to ferric iron. But in diabetic condition, due to glycation of ceruloplasmin, it acts as pro-oxidant which triggers ferrous ion stimulated peroxidation in formation of hydroxyl radical in Fentons reaction and donates free copper ions which induces reactive oxygen species, formation of low density lipodensity oxidation. The study is consistent with other studies. Also, Sharma et al., [45] reported higher level of ceruloplasmin in type 2 diabetes both with and without complication due to its compensatory mechanism to keep iron in ferric state and to prevent it to toxic effect. Mohiuddin et al., [32] found that higher level of ceruloplasmin was associated with increased glucose stimulated inflammatory reaction by increasing oxidative stress. In contrast to this study, Sarkar et al., [46] reported low level of ceruloplasmin in type 2 diabetes due to copper mediated generation of ROS, leading to increased consumption of available antioxidants in the body. Muhammad et al., [36] in a recent study observed no significant difference in the level of ceruloplasmin in type 2 diabetes. The progressive increase of ceruloplsmin observed in ages was not significant.

\section{CONCLUSION}

The findings of this study has shown that type 2 diabetics mellitus is associated with chronic low grade inflammation with an increase acute phase response by inflammatory protein These undesirable state which play roles in the pathogenesis of type 2 diabetes may result in unexpected complications increased morbidity and premature death in type 2 diabetics.

\section{REFERENCES}

1. World Health Organization. (2016). Global reports on Diabetes. In World Health Organization Library.Meo design and communication. France. 1-84.

2. Fareed, M., Salam N., Khoja, A., \& Abdulrahman, M. T. (2017). Life Style Related Risk Factor of Type 2 Diabetes Mellitus And Its Increased Prevalence in Saudi Arabia. International Journal of Medical Research And Health Science. 6(3): 125-132.

3. Iloh, G., Amadi, A., \& Ebirim, C. (2015). Type 2 Diabetes Mellitus in Ambulatory Adult Nigeria. British Journal of medicine and Medical Research. 1(3):1-12.

4. International Diabetes Federation. (2017). Diabetes Atlas. $8^{\text {th }}$ Edition. 1-45.

5. Adeloye, D., Ige, J., Aderemi, A., Adelaye, V., Amoo, E., Auta, A., \& Oni, G. (2017). Estimating the prevalence, Hospitalization and Mortality from Type 2, Diabetes Mellitus in Nigeria. Biomedical Journal Open.7 (5): 1-16.

6. Iloh, G., Chukwu, A., \& Amadi, A. (2013). Burden of Non - Communicable Disease among Geriatric Nigeria in a Rural-Constraited. Setting of Eastern Nigeria.Science Journal of Public Health, 1:141-146.

7. Mohiuddin, S. (2018). Association of Serum $\propto 1$ Acid Glycoprotein with Low Grades Chronic Inflammation in Pathogenesis of Diabetes Mellitus. Archives of Endomiology and Diabetes Care 11:3-10.

8. Chitra, Jayachandran, S., Darshan B., Mundinnnamane, D., Apoorva S., Divya B., \& Manjari, L. (2016). Acute Phase Proteins. Journal of Chemical and Pharmaceutical Research, 3(2): 368-370.

9. Ehiaghe, F., Agbanlahor, D., Tatfeng, Y., Ovisoejie, F., \& Ehiaghe, J. (2013). Serum CReactive Protein Level in Type 2 Diabetes Mellitus Attending Diabetic Clinic in Benin City, Nigeria. Journal of Diabetes Mellitus. 3(14): 168171. 
10. Salazar, J. Martinez, M., Chavez- Castillo, M., Nunez, V., Torres, A., Anez, K., Toledo, A., Chacin, M., Silva, C., Rojas. J., \& Bermadez, V. (2014). C- Reactive Protein: An In- Depth Look Into Structure, Function And Regulation. International Scholarly Research Notices. 653045: $1-45$

11. Burtis, C., \& Bruns, D. (2015). Individual Plasma Proteins In: Tietz Fundamental of Clinical Chemistry and Diagnostics. $7^{\text {th }}$ Edition. Saunders. Missouri. 300-307.

12. Mohiuddin, S., (2018). Low Grade-Chronic Inflammation in Pathogenicity of Diabetes Mellitus. Current Research in Diabetes and Obesity Journal. 5(4): 001-006.

13. MacKellar, M., \& Vigerust, D. J. (2016). Role of haptoglobin in health and disease: a focus on diabetes. Clinical Diabetes, 34(3), 148-157.

14. Mabayoje, V. O., Akanni, E. O., Arinola, G. O., \& Hassan, R. O. (2010). Plasma transferrin and caeruloplasmin levels in Nigerians with diabetes mellitus. Int J Trop Med, 5(1), 6-9.

15. Aronye, M. (2004). Size Determination In: Research Methodology with Statistics for Health and Social Sciences. $1^{\text {st }}$ Edition, Nathadex Publishers. Illorin, 115-121.

16. Tietz, J. (2006). Boss Hog: The Dark Side of America's Top Pork Producer. Rolling Stone.

17. Zeigenhagen, G., Dahovshy, D., Behovshy, D., \& Bedeutung, D. (1983). C-reactive protein. Medical Kin. 78:45 50.

18. Bergström, S. M. (1980). Conodonts as paleotemperature tools in Ordovician rocks of the Caledonides and adjacent areas in Scandinavia and the British Isles. Geologiska Föreningen $i$ Stockholm Förhandlingar, 102(4), 377-392.

19. Schmidt, C. (1975). Alpha 1- Acid Glycoprotein In: Plama Proteins.First Edition.Academic Press.USA. 184- 228.

20. Jacobs, D., De Mott, W.,Oxley, B. (2001):Plasma Proteins In: Jacobs and De Mott Laboratory Test Hand Book. Fifth Edition. Lexi Computer.1 -16.

21. Tabassun, R., Mia, A., Reza-UI-Hag, K., Yasmin, M., \& Farugui, W. (2017). C-Reactive Protein Level in Type 2 Diabetes Patients Attending My Mensinah Medical College Hospital. Mymensingh Medical Journal. 26(1): 56-60.

22. Cheng, L., Zhuang, H., Jang, H., \& Zhang, J. (2018). Exposing The Causal Effect Of CReactive Protein In The Risk Of Type 2 Diabetes Mellitus: A Medlian Randomization Study: Frontier In Genetics: 9. 627.

23. Mohieldein, A., Hasan, M., \& El-habiby, M. (2017). High sensitively $\mathrm{C}$ reaction protein as heterogenic marker among Type 2 diabetes European scientific journal. 13(33:403-416.

24. Babu, L., and Joshi, A. (2018): Correlation of High-Sensitivity C-Reactive Protein with Blood Sugar Level in Patients with Type 2 Diabetes.
National. Journal of Physiology Pharmacy and Pharmacology. 8(11): 37-41.

25. Salazar, A. (2018). No nacimos pa'semilla. AGUILAR.

26. Suensson, G., Mor, A., Rungby, J., Berencsi, K., Nielson, J., Stidsen, V., Friborg, S., Christensen, J., Nielsen, H., Sorensen, H., \& Thomsen, R. (2014). lifestyle and Clinical Factors Associated with Elevated C- Reactive Protein among Newly Diagnosed Type 2 Diabetes Mellitus Patients BMC Endorine Disorders. 14-74.

27. Tutuncu, Y., Satman, I., Celik, S., Dinccag N., Karsidag, K. Telci, A., Genc, S., Issever, H., Tuomilehto, J., \& Omer, B. (2016). A Comparison of Hs-CRP Levels in New Diabetes Groups Diagnosed Based on FPG, 2-HPG or HbAIc Criteria. Journal of Diabetes Research. 5827041: $1-9$.

28. Cardoso, L., Oliveira, A. C., Granada, S., Nachum-Biala, Y., Gilad, M., Lopes, A. P., ... \& Baneth, G. (2016). Molecular investigation of tickborne pathogens in dogs from Luanda, Angola. Parasites \& vectors, 9(1), 252.

29. Kanmani, S., Kwon, M., Shin, M., \& Kim, M., (2019). Association Of C Reactive Protein with Risk of Developing Type 2 Diabetes Mellitus and Role Of Obesity and Hypertension. A Large Population Based/Cohort Study. Scientific Report: 9:4573.

30. Gambineri, A., \& Pelusi, C. (2019). Sex hormones, obesity and type 2 diabetes: is there a link?. Endocrine connections, 8(1), R1-R9.

31. Abraham, P., Attipoe S., Kazman J., Zeno, S., Poth M., \& Deuster, P. (2017): Role of Plasma Adiponectin, C- Reactive Protein Ratio in Obesity and Type 2 Diabetes among African America. African Health Science. 17(1): 99-107.

32. Mohiuddin, S., \& Manjrekar, P. (2018). Role of Ceruloplasm as a Low Grade Chronic Inflammatory Marker and Activated Innate Immune System in Pathogenesis of Diabetes Mellitus. Journal of Diabetes Metabolic Disorders and Control. 5(4):148-152.

33. Abdulwahab, R., Alaigu A., Shinwari Z., Allaith A., \& Giha, H. (2019). LC MS/MS Protein Analysis Revealed Association Of 37 Protiens with 2D and Notable Upregulating of Immunoglobulins. International Journal of Molecular Medicine.43: 118 -2133.

34. Lee, J., Choi, J., Hwang, I., Lee, J., Kim, A., Huh, J., Koh, Y., Koy, G., Y., Son, H., Masuzaki, H., Hotta, K., Alfadda, A., \& Kim. J. (2010). Adipocytokine Orosmucoid Integrates Inflammatory and Metabolic Signals to preserve Energy Homeostasis by Resolving Immoderate Inflammation. The Journal of Biological Chemistry. 285(29): 2217r4 -22185.

35. Eldosky, M., Abdallah, A., Eldosky, N., Hassan, M., \& Eldosky, G. (2018). Role Of Acute Phase Proteins (Orosomuciod and Hs CRP) In Lean 
Type 2 Diabetic Patients With or Without Sub Clinical Altherosclerosis. American Journal of Medicine and Medicinal Science. 8(9): 219-275.

36. Mohammad I., Bourne, Y., Hedblad B., Nilsson P., Persson M., \& Engstorm G. (2016). Acutephase Proteins And Incidence Of Diabetes: A Population Based Cohort Study. Acta Diabetologia. 55: 981-989.

37. Kalis, M., Kumar, R., Janciauskiene, S., Salehi A., \& Cilo, C. (2010). $\propto 1$-Antibypsin Enhances Insulin Secretion and Prevents, CytokineMediated Apoptosis in Pancreatic $\beta$-Cells Islets 2:185-189.

38. Freixo, J., \& Rocha, Á. (2014). Arquitetura de informação de suporte à gestão da qualidade em unidades hospitalares. RISTI-Revista Ibérica de Sistemas e Tecnologias de Informação, (14), 1-15.

39. McCarthy, B., Casey, D., Devane, D., Murphy, K., Murphy, E., \& Lacasse, Y. (2015). Pulmonary rehabilitation for chronic obstructive pulmonary disease. Cochrane database of systematic reviews, (2).

40. Adinortey, M., Gyan B., Adjiman J., Nyarko P., Sarpong C., Tsikata F., \& Nyarko A. (2011). Haptoglobin Polymphosim And Association with Complications in Ghanaian Type 2 Diabetic Patients. Indian Journal of Clinical Biochemistry, 26(4): 366-372.

41. Hamdy, G., Hendy, O., Mahamoud, H., El Sebaey, A., Ali, S., \& Khalaf, F. (2014). Haptoglobin Phenotypes As a Risk Factor for Coronary Artery Disease In Type 2 Diabete.
Egyptian Journal of Medical Human Genetics. 15:3

42. Feng, C., Naik, B., Xin, W., Ma, J., Scalzo, D., Thide, H., Zuo, Z., Raphael, J., \& Thammishetti, S. R. (2017). Haptoglobin 2-2 Phenotype is Associated with Kidney Injury after Electric Cardiac Surgery in Patients with Diabetes Mellitus. Journal of the American HeartS Association. 111. 006565:1-12.

43. Olaniyan, O., \& Osadolor, H. (2018). Plasma Levels Of Haptoglobin Phenotypes With Vascular Complication In Nigerian Type 2 Diabetes. American Journal of Biomedical Sciences. 10(3): 184-188.

44. Mohieldein, A., Alzohuru, M., Hassan, M., \& Khan, A. (2012): Inflammatory markers and Haptoglobin Porymorphism in Saudi with Noninsulin Dependent Diabetes Mellitus: Global Journal of Health Sciences. 5(1):135-142.

45. Sharma, V., Tumbago, A., Pant, V., Aryal, B., Shrestha, S., Yadav, B., Tuiandhar, E., Bharttrai, A., \& Raut, M. (2018). Ceruloplasmin A Potential Marker For Glycaemic Status and Its Relationship with Lipid Profile In Type II Diabetes. Asian Journal of Medical Sciences. 9(2):13-18.

46. Sarkar, A., Dash, S., Barik, M., Mutttigi, M., Kedage, V., Shetty, J., \& Prakash, M. (2010). Copper and Ceruloplasmin Levels In Relating Total Thiols and GST in Type 2 Diabetes Mellitus Patients. Indian Journal of Clinical Biochemistry. 25(1):74-76. 